\title{
The Response of Milenial Muslim Generations to The Tradition of Kungkum Purnama in Banjarpanepen, Banyumas, Indonesia
}

\author{
${ }^{1}$ Saridin, ${ }^{2}$ Agus Ujianto, ${ }^{3}$ Abdul Basit \\ $1,2,3$ State Islamic Institute of Purwokerto \\ Jl. A. Yani 40-A (+62 281) 635624 Purwokerto 53126 \\ E-mail: saridin1973sumpiuh@gmail.com, ujiantoagus@gmail.com, \\ abdulbasit1969@gmail.com
}

Abstract: Islam entered the island of Java with the condition that the people already have traditions. One of the traditions that still exist today is Kungkum Purnama in Kalicawang, Banjarpanepen Sumpiuh Village, Banyumas District. The Kungkum Purnama tradition is carried out every year in the month of Sha'ban as a form of welcoming the month of Ramadan for Muslims. The implementation of the Kungkum Purnama tradition is followed by village communities who are not only Muslim, but also those who are non-Muslim or religious. It cannot be denied that the Muslim millennial generation is one of the heirs to tradition. This study aims to describe the response of the Muslim millennial generation to the kungkum purnama tradition. In practice, researchers used qualitative research methods of field research type. Data were collected by means of observation, interviews and documentation. The analysis was carried out by collecting data, reducing data, presenting data, and drawing conclusions. The results showed that the Kungkum Purnama tradition is a form of acculturation of Islam with Banyumasan culture, which contains social and religious values, namely Islamic syiar, to welcome Ramadan, friendship, and clean oneself. The response of the Muslim millennial generation shows their view of the kungkum purnama tradition. From a religious perspective, the practice of the kungkum purnama tradition on the other hand contains teachings that are contrary to Islamic teachings. From a cultural point of view, the kungkum purnama tradition is a local tradition and a tourist attraction that needs to be preserved. From a social 
IBDA': Jurnal Kajian Islam dan Budaya

point of view, the kungkum purnama tradition contains the values of cooperation, mutual cooperation, and togetherness

Keywords: Muslim millennial generation, tradition

\section{A. IntRODUCTION}

Ramadan is a special month for Muslims. The Muslim community believes that the month of Ramadan is the most glorified month among other months, in which all Muslims who meet the requirements, are obliged to fast. Not only is it an obligation, but fasting in the month of Ramadan is a practice that has many virtues. Therefore, the month of Ramadan is the month that has been eagerly awaited and welcomed by the Muslim community.

In Indonesia, there are various forms of "welcoming" the month of Ramadan by Muslims. The reception, for the most part, has become a community tradition on an annual basis. The tradition of welcoming the month of Ramadan has been carried out in several cities in Indonesia; such as the traditions of Mangan Fajar, Marpangir, and the Grave Pilgrimage carried out by the Mandailing and Angkola communities in North Sumatra (Siregar, 2020). The tradition of the torch parade in the city of Pontianak (Fathurrosi, 2020). the art of parading performed in Semarang City in ceremonies Dugdheran (Cahyono, 2006).

The people of Banjarpanepen village also welcome the month of Ramadan, namely the Kungkum Purnama or Mandi Sadran tradition in Kalicawang. This tradition is a form of gratitude by celebrating the coming of the blessed month. The Kungkum Purnama tradition is not just a ritual without any value in it, but it is full of values contained in it. Historically, the Kungkum Purnama tradition is related to how Islam entered the Panepen area, which is included in the Sumpiuh Banyumas sub-district.

The Kungkum Purnama tradition has been going on for a very long time, even according to Kiai Sholeh, one of the descendants of Kasepuhan, Banjarpanepen Village, it has been a long time since our ancestors as a form of culture that occurred as a result of adjusting Islamic teachings to local culture. Even this tradition has now become very unique because not only Muslims do it to welcome the coming month of Ramadan, but followers of other religions and beliefs also participate in the Kungkum Purnama. 
Saridin et al.: The Response of Milenial Muslim Generations to The Tradition of

Kungkum Purnama in Banjarpanepen, Banyumas, Indonesia (page 351-368)

The preservation of culture and tradition depends on the influence of changing times and the actors of the tradition themselves. Not a few traditions are extinct because they are considered outdated. In the technology era, millennials tend to be more interested in things that are booming. All activities carried out turn to cyberspace, such as the internet. They prefer to interact and express themselves on social media. Arum Faiza et al stated that the millennial generation cannot be separated from gadgets (Faiza, 2018). This will certainly have an impact on the existence of old traditions.

Apart from this phenomenon, the Kungkum Purnama tradition still exists today. This sustainability is inseparable from the generation of local people, how they try to maintain traditions in the midst of technological incessant. As part of a community that has traditions, it is important to know how the millennial generation responds to the Kungkum Purnama tradition.

\section{B. Literature ReView}

Not a few researchers have examined local traditional values from an Islamic perspective. As in the research conducted by Fathurrosi entitled "The Tradition of the Torch Parade Welcoming Ramadan in the Perspective of Cross-Cultural Communication in the Community of Pontianak City". The results of this study found that the tradition of the torch parade in order to welcome Ramadan is a form of preserving local culture. The torch parade is a form of perception built in the form of activities so that prejudice does not occur which results in conflicts with other cultures. Pontianak Muslims participated in the torch parade without limiting it to certain tribes. This means that anyone has the freedom to participate in these activities. This tradition is a call to return to character and life based on love and togetherness as social beings (Fathurrosi, 2020).

Research on the tradition of welcoming the month of Ramadan was also carried out by Muhammad Andre Syahbana Siregar with the title "Ziarah Kubur, Marpangir, Mangan Fajar: Traditions of Angkola and Mandailing Communities to Welcome the Month of Ramadan and 'Eid Al-Fitr". The findings of this study are that the local traditional values of the Angkola and Mandailing people still go hand in hand with the teachings of Islam. Pilgrimage to the Grave is a tradition of visiting the grave which is carried out every year before Ramadan. Marpangir is a pangir bath tradition so that the body is clean and fragrant to welcome the holy month. The people of Angkola and 
Mandailing believe that marpangir can drive away their lust of anger, envy and envy (Siregar, 2020).

The study of the tradition of welcoming the month of Ramadan above focuses more on Islamic values contained in the tradition, but does not discuss how people - who are in the category of the millennial generation, take their attitudes and how they view this tradition. As it is known, the millennial generation is a generation born in an era of digitalization where technology and information systems are developing rapidly (Tulung, dkk., 2019) Their curiosity about all the new things that are spread in cyberspace is greater than their curiosity about the real things around them.

A similar study was conducted by Mohamad Sobirin with the title "Negotiating Tradition and Innovation Upon the Cross-Generational Art of Singiran (Improvisation, Cultural Identity and Millennial Community). From this research, it is found that millennial Muslims have made innovations in the Singiran tradition. The innovations made include performance and arrangement innovations. The new function of the Singiran tradition in the context of millennial Muslims is as entertainment, a form of cultural identity, and spiritual-ethical attachments (Sobirin, 2020). The focus of research conducted by Mohamad Sobirin is more on the implementation of innovation on the tradition and meaning of Singiran for the millennial Muslim community in the context of Javanese Islamic culture.

Another research conducted by Muhazzab Said which is published in the international journal JICSA with the article title "A study of the Acculturation of Islam and Local Culture Bungamale as a Local Culture of South Sulawesi". The results of this research are Bungamale is a tradition of coloring eggs in the month of Rajab which has positive values; including as a communication medium to get the attention of Muslims, especially children, to gather and listen to the history of the life of the Prophet Muhammad, to build cooperation and collaboration between Muslims of different RT, RW, and village. Bungamale itself as a symbol of beauty or beauty; where the Prophet Muhammad as uswatun hasanah was followed in every aspect of his life, especially the beauty of his character (Said, 2015).

Research conducted by Muhazzab Said focuses more on studying the form of acculturation of the Bungamale tradition with Islam and the positive values contained in this tradition, not discussing how the millennial generation responds to the existence of the Bungamale tradition in the month of Rajab. 
Saridin et al.: The Response of Milenial Muslim Generations to The Tradition of Kungkum Purnama in Banjarpanepen, Banyumas, Indonesia (page 351-368)

From some of the literature reviews, it can be said that this research is a study that has never been done by previous researchers. Therefore, the findings from the results of this study can provide scientific contributions, especially in understanding the response of the millennial generation to local traditions that have experienced acculturation with Islam.

\section{Research Methode}

In order to understand the socio-cultural aspects of the Banjarpanepen Village community, especially regarding the Kungkum Purnama Tradition in Kalicawang, ethnographic research is necessary. This type of research used by researchers is qualitative research. Margono explained that qualitative research is research that will produce descriptive data in the form of words; both orally and in writing (Margono, 2005). This research includes the type of field research, as well as research library research types. This research process took data sources from the Banjarpanepen Village community, especially community leaders and several informants.

The approach used by researchers in this study is historical-philosophical, namely an attempt to see the problem from a historical point of view. Researchers explore the journey of the kungkum purnama tradition in Kalicawang. In addition, researchers also use a socio-cultural approach, because this research deals with people's behavior or habits that affect people's knowledge, perceptions, attitudes, and beliefs.

The data collection was taken from the results of observations (observations of the environment and habits carried out by the community on a daily basis) and in-depth interviews with community leaders and the millennial generation. The number of respondents to obtain data, researchers did by taking $10 \%$ of the total number of millennial generations (aged 20 to 39 years) in Banjarpanepen. The total number is 1,556 people, so that $10 \%$ of the total is 156 people. In determining a sample of 156 people, researchers used a snowball sampling technique. Apart from that, the researcher also collected data in the form of text which was considered supportive and representative as well as documentation or photos of community activities that were related to the title of this research.

Researchers conducted data analysis by reducing the data that had been collected. After the data is reduced or sorted which are important and representative, then the researcher presents the data as well as analyzes the data in 
the form of a description. Finally, the researchers made conclusions about the research results.

\section{Result AND Discussion}

\section{Kungkum Malam Purnama Tradition}

Kalicawang River is located in Banjarpanepen Village, Sumpiuh District, Banyumas Regency. In the Kalicawang complex, there is a petilasan $\mathrm{Ki}$ Rantamsari or grandmother Gendeng. The people around this river have a unique tradition, namely bathing or kungkum on the full moon.

Bathing or kungkum purnama is a bath performed by the people around Banjarpanepen Village every 14 Sadran or the night of 15 Sya'ban. The implementation is in Tempuran Kalicawang, Tempuran means the place where two rivers meet, the place is believed to be sacred.

On the 14th of Sya'ban or Sadran, the entire community, from the old to the young, and all religious adherents who were present gathered around the Kalicawang battle. The Kalicawang complex has been decorated with a torch that illuminates the entire Kalicawang complex. At exactly 12.00 WIB at night or at $00.00 \mathrm{WIB}$ all torches and lights were turned off, all that was left was only one torch that was carried by one of the residents only to illuminate the Village Head into the river.

This tradition was preceded by the handing of the Penjalin Pethuk stick to the village head. In addition, there are also those who sweep the road with a broom stick as a sign that the road is clean and safe. This clean and safe road will be traversed by village heads and religious leaders, as well as the community present. The procession of village heads, religious leaders, and the community is accompanied by the Javanese repertoire of the song dandang Gula and lir ilir. Then everyone follows into the Kalicawang river to kungkum or take a shower without making a sound or silence.

The Kalicawang River, which is in a mountainous area, has very clear and cold water like ice, especially at night. According to the village elder of Banjarpanepen, Samingin, it is believed that on the night of 15 Sha'ban the gods or angels descended on earth around the world because they wanted to see the clarity and beauty of the Kalicawang river. According to information, when the gods and angels arrived at the river, the river water would die or stop flowing. At that time the river water dies or stops, it is believed that whoever 
Saridin et al.: The Response of Milenial Muslim Generations to The Tradition of

Kungkum Purnama in Banjarpanepen, Banyumas, Indonesia (page 351-368)

takes a bath or kungkum in the river will have a great blessing and his wish will be granted.

Regardless of rank, young age, and religion, people can follow kungkum together. All people who take a bath together or kungkum are scattered with flowers of the seven forms. The religious leaders offered prayers for all present. After the religious leaders say a prayer, each person who takes a bath or kungkum then says a prayer to be given blessings, holiness, and added fortune for entering the month of Ramadan.

This tradition has been passed down from generation to generation. The public does not know how this tradition emerged. The procession of bathing or kungkum on the full moon to be precise in the month of Sha'ban in the Kalicawang River is preceded by fasting first, bathing in 7 wells, and ending with kungkum in the Kalicawang river.

People believe that bathing or kungkum can dissolve sins, cleanse the heart, and also eliminate various diseases. In fact, sometimes from afar there are those who come to follow the ritual, besides that, so that sustenance is smoother, it can also increase the rank or degree of officials.

The kungkum or bathing ritual in Kalicawang once stopped in the 80s, although the official event stopped, the kungkum ritual was still running and there were quite a lot of participants. Unfort unately the ritual bathing or kungkum is not well organized.

Around 2015, when the Head of Banjarpanepen Village was held by Mr. Mujiono this tradition was revived and even made a tourist site, and a Tourism Awareness Group (Pokdarwis) was formed which was chaired by Mr. Turimin. According to the head of Desa Mujiono as conveyed by Samingin, kungkum or bathing in Kalicawang makes humans more cool and clear; cool heart and clear mind.

Banjarpanepen Village besides having Kalicawang with good and beautiful scenery, the community is very unique. This uniqueness is that the religions and beliefs of the people of Banjarpanepen Village are very diverse, it can even be said that all religions, even religious and Javanese beliefs and places of worship are there.

They live in harmony even though they are full of differences, are used to working together and live in mutual cooperation, love, hone, and care for each other without differentiating their religious backgrounds and beliefs. 
They are used to working together in carrying out activities; such as building a place of worship, for example if a mosque is being built other religions also help. In carrying out religious activities, they also take part in it; such as commemoration of Islamic holidays, those who are not Muslim attend the event. During the Hajj, too; they help each other, the women cook in the kitchen and the men make tratags without distinguishing religion.

\section{Social and Religious Values from the Kungkum Purnama Tradition}

Humans are born natural and consist of various ethnic groups so that they know each other. Allah SWT gives advantages to humans in the form of minds so that humans have different cultures according to their adjustments to the nat ural surroundings. In addition to adjustments to the surrounding environment, it is also due to differences in understanding of the guidance of the book of Allah brought by the messengers. Therefore, a social product of the community or commonly referred to as a tradition that varies between regions was born.

From observations and interviews conducted, the tradition of bathing in the full moon or kungkum in Kalicawang is indirectly part of the community's response to Islamic teachings, and is a form of cultural reception for the verses of the Qur'an. The kungkum purnama tradition contains the following values of Islamic teachings.

\section{a. As a Syiar of Islam}

Rasulullah Saw in preaching to the Arabs did not use violence, but by means of amar ma'rüf and nahī munkar. Judging from the editorial, then amar ma'ruf takes precedence. Ma'ruf here means "good". Not only good individually, but also collectively and contain mutual benefits. The preachers must consider the good and bad steps taken in carrying out the spread of Islam. The concept of amar ma'ruf nahi munkar is the best way to form a harmonious community. Allah Almighty said in Qs. Al-A'raf verse 157.

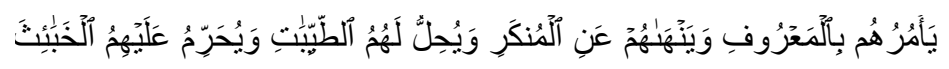

... who orders them to do what is bad and forbids them from doing what is bad and makes them all good and forbids everything that is bad.

Ibn Taymiyyah explained that the verse contained the clarity of the treatise that was given to Muhammad Saw. Allah is the one who commands to 
Saridin et al.: The Response of Milenial Muslim Generations to The Tradition of Kungkum Purnama in Banjarpanepen, Banyumas, Indonesia (page 351-368)

invite things that are wrong and prevent things that are wrong (Taimiyah, 2001). Rasulullah Saw used 'Amar Ma'ruf Nahi Munkar in spreading the teachings of Islam, so it is not justified to do preaching by means of insults.

In this case, bathing or kungkum in Kalicawang is formed as a means of preaching so that humans get closer to their creators. This is in accordance with the word of Allah Surah Al Imron verse 104, which reads.

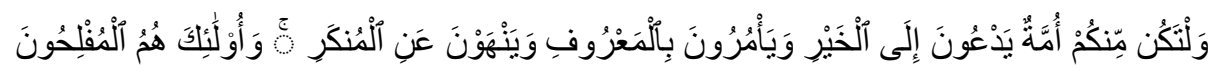

"And let there be among you a people who call on virtue, command the good and prevent the evil; they are the lucky ones."

The existence of Islamic syiar which is carried out through traditions such as Mandi or Kungkum Purnama in Kalicawang, is an indication that there is a link between Islamic teachings and local culture. The relationship between local culture and Islamic teachings gave birth to a distinctive Islam. An example in this case is Islam Nusantara. According to Gus Dur, this phenomenon is one proof that Islam which is developed and embraced by the majority of society is spread by the ulama in a peaceful way through a cultural approach, in this way Muslims in various regions of the archipelago can easily accept and understand Islamic teachings (Wahid, 2006).

The method of da'wah used by the ulama to spread Islamic teachings through local traditions or culture is very appropriate, because changing the traditions or customs of the community is a very sensitive matter and is prone to division and rejection. So that by preserving the existing community traditions, and incorporating Islamic teachings into them is a very appropriate da'wah step.

Millennials, as the successors to the spread of Islam, should understand the steps taken by previous preachers. In this regard, understanding local customs and culture is important for the millennial generation. In addition to remembering the historical traces of the spread of Islam, it is also a lesson for moderate Islamic syiar or commonly known as wasathiyah. Syiar Islam wasathiyah becomes a form of da'wah to ward off radicalism.

\section{b. As A Means of Gathering and Cleaning Yourself}

For the people of Banjarpanepen Village and its surroundings, bathing or kungkum in Kalicawang is a tradition that is awaited by the community because besides being able to carry out rituals to clean themselves as well as 
a means of keeping in touch, even people who are overseas also return to follow it. They can gather with family, relatives and friends who sometimes have not seen each other for a long time because of their busy lives. Moreover, those who attended did not know religion or rank, all of them became one to carry out the kungkum tradition activities in Kalicawang.

In the teachings of Islam, someone who maintains friendship will be added with his sustenance. In Qs. Ar-Rum verse 37, Allah SWT said:

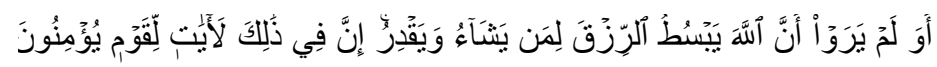

And do they not pay attention that Allah enlarges sustenance for whom $\mathrm{He}$ wants and $\mathrm{He}$ (also) constricts (that provision). In fact, in this there are signs (power of Allah) for the believers.

Various ways can be done to maintain friendship. Each region has a different form of silaturrahim. However, the culture of silaturrahim can be maintained if there are examples from the old generation to the new generation. The Kungkum tradition can be used as a means to cultivate hospitality to the millennial generation.

\section{c. To Welcome Ramadan}

Some of the advantages in the month of Ramadan are that Allah sent down the Qur'an through his angel to the Prophet Muhammad, Allah has opened the gates of heaven for Muslims, and closed the gates of hell. At the time of the full moon of Sya'ban, it means that Romadhon is less than 15 days away. Most Muslims have prepared themselves both physically and mentally.

Kungkum in Kalicawang to clean the body physically. However, this ritual is a symbol to cleanse the heart and mind of immorality and worldly love. This is also reflected in the presence of people who gather to bathe together, do not recognize the rank and position of rich or poor. In Islamic teachings, water is used as a tool to cleanse and purify. Dohir cleanse the physical, but with the intention because of Allah and accompanied by dhikr (remembering) Him, it will clean the spiritual aspects of humans. Allah has also said in Qs. Az-Zumar verse 23, which contains things that need to be done in order to cleanse the heart and mind.

On the 14th of Sya'ban the night is known as the night of nisfu sya'ban which for Muslims believes it is a glorious night, on that night it is used to worship Allah SWT. In this case, the worship performed by the Banjarpanepen 
Saridin et al.: The Response of Milenial Muslim Generations to The Tradition of Kungkum Purnama in Banjarpanepen, Banyumas, Indonesia (page 351-368)

villagers is manifested in the form of the kungkum purnama tradition with various ritual processions in it. The existence of Islamic teachings does not necessarily eliminate traditions that have taken root in society. Even by Kuntowijoyo, this is a form that Islam is a collective religion. This means that the teachings of Islam, including worship ordered by Allah Most High, can be carried out collectively. Worship that is carried out collectively will give a sense of enthusiasm in carrying it out and grow a sense of togetherness among adherents.

This feeling of enthusiasm is expected to emerge in the millennial generation as the successor to the preaching of Islam. Millennial generation is a generation that has individual tendencies. Therefore, collective expressions of gratitude will minimize individualism.

\section{Islamic Acculturation with Banyumasan Culture}

Some experts state that Islam entered Indonesia since the 7th century AD or in the Hijriyah calendar entered in the first century. In addition, there is an opinion that in the 13th cent ury AD Islam only arrived in Samudra Pasai. Some experts argue that Islam has come to Indonesia since the first century Hijriah or around the 7th century $\mathrm{AD}$, and some argue that Islam only arrived in the 13th century AD, especially in Samudra Pasai. Historians have created three theories about who brought Islam to the archipelago, namely the theory of Makkah, Gujarat, and Persia. The three theories are based on their respective evidence.

According to Taufik Abdullah (Abdullah, 1991), the three theories are seen as complementary regardless of differences. This is reinforced by the existence of a religious style of Islam in Indonesia which is influenced by three cultural features, namely Persian, Mecca, and Gujarati. The influence of the Syafi'i mazhab which is used as a mazhab by most Muslims in Indonesia, is evidence of the influence of Mecca. The thickness of the Sufi world with Shi'a features by the Indonesian Muslim community is evidence of the great influence of Persia. Apart from these two influences, there is an influence from Gujarat which can be seen from the government and the shape of the building.

Islam was able to develop on the island of Java because of the progress of Wali Songo, namely between the 15 th and 16 th centuries AD, but the establishment of the Saka Tunggal "Baitussalam" Mosque in Cikakak Village, Wangon District, Banyumas Regency, Central Java Province, is proof that 
Islam has developed long before the Wali Songo era. In the mosque, the year engraved on Saka Guru is 8821 in Arabic letters, which means the year 1288 AD (Faiz, 2020).

If you refer to this fact, there is a possibility that Islam entered Banjarpanepen village before the Walisongo era because Banjarpanepen village is still one district with Cikakak village. However, to know specifically when Islam began to enter Banjarpanepen Village is very difficult to determine the right time. Apart from the fact that written evidence was not found, it was also because the residents had very little knowledge of it. The residents only know that there is a Musola which was first established. The prayer room which is now the Banjarpanepen Village Mosque, which is located not far from Kalicawang.

According to Samingin, the first prayer room that was available was that of Mr. Kayim. When viewed from the lineage or family lineage of Mr. Kayim, it shows that he is still in the lineage of Kiai Wayahe whose grave is in Banjarpanepen. Therefore, what Mr. Kayim said that his prayer room was the first to exist is the truth.

Bathing in Kalicawang is like an activity depicted in the Javanese song Dandanggula macapat, which reads ojo turu sore kaki, ono dewo lawang jagat, nyangking bokor kencanane isine dunga tetulak sandang kelawan pangan iku bageani wong kang sabar lan narimo. The Dandanggula macapat song was created by Sunan Kalijaga. The song has been recognized by the community, especially religious leaders in Banjarpanepen Village. This means that the previous preachers in the village had introduced the Dandanggula macapat poetry to the previous community. This is proof that Islam is spread with Javanese poetry that are easily accepted and understood by the people of Banjarpanepen Village.

Furthermore, Samingin said that bathing in Kalicawang is carried out after $12 \mathrm{o}$ 'clock in the evening and it is believed that there are angels or gods who travel the world to share sustenance for humans who are patient and sincere. What Samingin said was a form of understanding of the meaning of the Dandanggula macapat song above. and has entered the realm of public belief. As a manifestation of the belief that one should not sleep at night nisfu Sya'ban because an angel will come down to share the sustenance, the people take a kungkum bath in Kalicawang. That way, they will stay awake from sleep. 
Saridin et al.: The Response of Milenial Muslim Generations to The Tradition of Kungkum Purnama in Banjarpanepen, Banyumas, Indonesia (page 351-368)

Islam in Indonesia is a new religion because people in Indonesia have embraced Hinduism, Buddhism and beliefs before the arrival of Islam. The initial process of converting to Islam is an important thing in the history of the nation. This is because Islam entered Indonesia in a very peaceful way and there was no fighting or war.

Referring to this, it means that Islam entered Banjarpanepen Village in a very peaceful way. The people of Banjarpanepen village have Hindu and Buddhist religions. In the process there was assimilation between Islam, Hinduism and Buddhism so that they influenced each other. All will maintain their rooted traditions, but on the one hand they must also be willing to openly accept the new tradition for good in the sustainability of people's lives.

The tradition of bathing or kungkum in Kalicawang is indicated as a tradition that emerged from the peaceful Islamization process through a cultural approach. What is unique here is that the process of Islamization with an accommodative model is similar to the development of Islam and multiculturalism that existed at the time of the Prophet Muhammad. At the time of the Prophet Muhammad, monotheism was propagated by accommodating the cultural system that had been formed in Arab society. It can be said that Islam entered Banjarpanepen Village by accommodating the existing culture in the community.

\section{Response of Muslim Millennial Generation}

Millennial generation is the generation that was born after generation X. There are several names for the millennial generation, including the $\mathrm{Y}$ generation, the Me Me Me generation, and the Net generation. They were born between the 1980s and 2000s. For the millennial generation, having a social media account is mandatory. Not only that, through the sophistication of technology and the fast flow of information, they are always up to date on new trends. Therefore, traditions that are updated on social media, and have experienced innovations that are collaborated with current trends, still have an appeal to the millennial generation; such as the revitalization of the Lontar Yusup mocoan tradition in Banyuwangi so that the preservation of the tradition is maintained, especially in the millennial generation.

The kungkum purnama tradition is one of the various traditions that still exist but have not or have not experienced innovation or revitalization. This tradition is still pure, since it was first formed until today. Based on the results 
of interviews with 156 millennial generations in Banjarpanepen Village, there were 15 respondents who did not agree with this tradition and the remaining 141 respondents agreed with the kungkum purnama tradition.

Based on the results of the interview, there were various reasons for their disapproval; such as fear of being sick because the kungkum tradition is carried out at night, lazy to leave because of the distance from the house to the location, it is feared that it will pray to other than Allah, and will cause immorality because men and women have no boundaries. Although they do not agree, they do not reject or try to oppose the kungkum purnama tradition. They don't follow tradition, but leave people who are willing to follow that tradition.

Then as many as 141 respondents who agreed, had various reasons. The response of the millennial generation shows their view of the Kungkum Purnama tradition. The views of the millennial generation on the Kungkum Purnama tradition, the authors categorize it into three, namely from a religious, social, and cultural point of view.

\section{a. From Religion Point of View}

Even though the millennial generation views that Kungkum Purnama is a local tradition and a tourist attraction that must be preserved, they as adherents of the Islamic religion consider that the ritual is not Islamic teachings, even in its implementation there needs to be new rules in accordance with Islamic teachings; for example, between men and women there needs to be a barrier. This is as stated by Sutriyanto, one of the respondents during the interview.

"There must be a boundary between men and women according to the religious law."

In Islamic teachings, the relationship between a man and a woman who is not a mahram is very concerned. The kungkum purnama tradition is carried out jointly by both men and women in one place, namely Cawang River. The Muslim millennial generation views that this is not justified in the teachings of Islam. Therefore, not many Muslim millennial generations follow the Kungkum Purnama ritual.

Their view of the Kungkum Purnama tradition which is contrary to the teachings of Islam shows that their underst anding of the acculturation of Islam with the Banyumasan culture is still low. They do not understand that in the 
Saridin et al.: The Response of Milenial Muslim Generations to The Tradition of

Kungkum Purnama in Banjarpanepen, Banyumas, Indonesia (page 351-368)

Kungkum Purnama tradition there are Islamic religious values. Therefore, it is important for religious leaders in Banjarpanepen Village to provide a deeper understanding of the teachings of Islam.

On the other hand, their acceptance of the Kungkum Purnama tradition is only a form of respect for tradition and culture, as well as for inter-religious harmony. Tradition has the function of unifying the people. Therefore, its existence is important in order to avoid division between people. Islam has taught tolerance (Fadli, 2019), so it is fitting for the Muslim millennial generation to apply this attitude in life.

\section{b. From Culture Point of View}

Communities in certain areas have different traditions from people in other areas. The traditions of the local community are known as local traditions. Usually, small-scale communities have the same traditions, culture, and religion, on the other hand, heterogeneous communities tend to have different religious traditions but side by side (Syukur, 2018). This is different from the people in Banjarpanepen Village who are heterogeneous but have one common tradition, namely Kungkum Purnama. The following is the statement of Almabarrun and Ramadhani as millennial generations about the Kungkum Purnama tradition.

"A unique tradition that needs to be preserved for religious harmony."

This statement shows the awareness of the millennial generation that an area has a tradition as wealth that must be preserved. The survival of a tradition depends on the millennial generation as heirs.

On the way, tradition is not only a ritual performed by traditional actors; it has entertainment value. Therefore, many traditions have developed into tourist objects. As millennial generations, Sutriyanto and Duwi Iryani said that the Kungkum Purnama tradition can be a tourist attraction. The following is the second speech.

"This tradition (Kungkum Purnama) can be used as a tourist attraction that needs to be preserved so that it is not eroded by the times."

Tradition is a unique product of society, so it is not surprising that on its way it becomes a tourist attraction that has appeal to the public. If the community is able to read opportunities and innovate on traditions, it is not impossible that a tradition will become a tourism object that has economic value and improves people's welfare. 


\section{c. From Social Point of View}

One of the millennial Muslims who have participated in the Kungkum Purnama ritual only considers this tradition to be an Indonesian culture that needs to be preserved and there is an element of togetherness that is felt. The following is the response of one respondent named Nur Wahid Jailani during an interview with the researcher.

"Yes (I have followed the Kungkum Punama tradition), because I consider it an Indonesian culture that we need to preserve. I feel there is togetherness".

In essence, humans like the existence of togetherness because humans are homo sapiens who cannot live their own lives. Togetherness with others will give you peace of mind. The tradition of Kungkum Purnama as one of the platforms that gives rise to togetherness is felt by the Muslim millennial generation who have experience by following directly.

In addition, the implementation of the Kungkum Purnama tradition can create an attitude of mutual cooperation between residents because it is impossible for a tradition to be carried out without the cooperation of various parties. This is where the mutual cooperation between religious communities and local beliefs emerges. The Muslim millennial generation as part of the citizens who have the Kungkum Purnama tradition, also plays a role in making preparations in the field.

\section{E. Conclusion}

Java Island is inhabited by people who have various traditions. This tradition has been acculturated with Islam. Kungkum Purnama in Kalicawang as one of the traditions on the island of Java to be precise in Banjarpanepen Village, which has experienced the acculturation of Islam with Banyumasan culture. This tradition contains social and religious values.

The Muslim millennial generation knows the existence of local traditions, especially the Kungkum Purnama tradition and has an awareness of the importance of preserving this tradition. They do not follow rituals that are considered contrary to their understanding of the teachings of Islam. However, they do not reject the existence of the Kungkum Purnama tradition because it prioritizes tolerance to create religious harmony. In addition, the kungkum purnama tradition contains the value of togetherness. 
Saridin et al.: The Response of Milenial Muslim Generations to The Tradition of Kungkum Purnama in Banjarpanepen, Banyumas, Indonesia (page 351-368)

\section{REFERENCES}

Abdullah, Taufik. 1991. Sejarah Umat Islam Indonesia. Majelis Ulama Indonesia.

Abdurrahman, Dudung. 2014. Komunitas-Multikulturalisme dalam Sejarah Islam Periode Klasik. Yogyakarta: Penerbit Ombak.

Cahyono, Agus. 2006. "Seni Pertunjukan Arak-Arakan dalam Upacara Tradisional Dugdheran di Kota Semarang." Harmonia 7, no. 3: 1-11.

Fadli, Subhan. 2019. "Membangun Toleransi Generasi Milenial." Prosiding Seminar Nasional, Harmonisasi Keberagaman dan Kebangsaan Bagi Generasi Milenial, Lembaga Kajian Keagamaan, Universitas Pamulang, 2019, 120-36.

Faiza, Arum. 2018. Arus Metamorfosa Milenial. Kendal: CV Ahmad Jaya Group.

Fariz, Ahmad. 2020. Biografi 20 Ulama Banyumas. Banyumas: Satria Indra Prasta (SIP) Publishing.

Fathurrosi. 2020. "Tradisi Pawai Obor Menyambut Ramadhan dalam Perspektif Komunikasi Lintas Budaya pada Masyarakat Kota Pontianak." Jurnal Ilmu Komunikasi PROGRESSIO 1, no. 2: 113-31.

Jeane Marie Tulung, Achmad Syahid, Yanice Janis, Yan O Kalampung. 2019.

Generasi Milenial. Depok: PT RajaGrafindo Persada.

Margono, S. 2005. Metodologi Penelitian Pendidikan. Jakarta: Rineka Cipta. Rohman, Kholilur. 2020. Membentuk Generasi Milenial dengan AjaranAjaran NU Yang Berhaluan Aswaja Desa Kertosono. LITBANG PEMAS UNISLA.

Said, Muhazzab. 2015. "A Study on the Acculturation of Islam and Local Culture." Journal of Islamic Civilization in Southeast Asia 4, no. 2: 76-100.

Siregar, Muhammad Andre Syahbana. 2020. "Ziarah Kubur, Marpangir, Mangan Fajar: Tradisi Masyarakat Angkola dan Mandailing Menyambut Bulan Ramadhan dan 'Idul Fitri." Warisan: Journal of History and Cultural Heritage 1, no. 1: 9-13.

Sobirin, Mohamad. 2020. "Negotiating Tradition and Innovation Upon the Cross-Generational Art of Singiran (Improvisation, Cultural Identity and Millennial Community)." Teosofia 8, no. 1: 69. https://doi.org/ 10.21580/tos.v8i1.5300. 
IBDA': Jurnal Kajian Islam dan Budaya

Syukur, Abdul. 2018. Tantangan dan Harapan dalam Membangun Masyarakat Islam. Bandung: Madrasah Malem Reboan. http://library1.nida. ac.th/ termpaper6/sd/2554/19755.pdf.

Taimiyah, Ibnu. 2001. Etika Beramar Ma’ruf Nahi Mungkar. Jakarta: Gema Insani Press.

Wahid, Abdurrahman. 2006. Islamku, Islam Anda, Islam Kita. Jakarta: Wahid Institute. 